\title{
On evaluating the potential of nanocomposites for heavy oil recovery
}

\author{
Hiroki Inoue $^{1} \cdot$ Ronald Nguele $^{1}\left[\right.$ ] Nchimi Nono Katia ${ }^{2} \cdot$ Kyuro Sasaki $^{1}$
}

Received: 9 December 2020 / Accepted: 3 February 2021 / Published online: 3 March 2021

(c) The Author(s) 2021

\begin{abstract}
The present work investigates potential of nanocomposite (NCP) for enhancing the production in heavy oil formation. NCP was extracted from bauxite ore and the spectral characterization revealed that NCP was a crystalline material whose matrix consists of 64.5 wt.\% alumina oxide $\left(\mathrm{Al}_{2} \mathrm{O}_{3}\right), 15.7$ wt.\% iron oxide $\left(\mathrm{Fe}_{2} \mathrm{O}_{3}\right)$, and 19.8 wt.\% silica oxide $\left(\mathrm{SiO}_{2}\right)$. The nanocomposite fluid, obtained by dispersing NCP into the targeted formation brine, showed a good dispersion over the two first days beyond which a hetero-aggregation, visible to the naked eye, was observed. Coreflooding assays, performed on Berea sandstone saturated with a heavy mineral oil $\left(\rho=0.854 \mathrm{~g} / \mathrm{cm}^{3}\right)$, revealed that $0.25 \mathrm{wt} . \%$ of NCP dispersed in the formation brine yields a poor recovery. However, increasing the load in NCP from 0.25 to $0.75 \mathrm{wt} \%$ and subsequently $1 \mathrm{wt} . \%$ using the same formation brine, showed an increase in the oil recovery up to $14.1 \%$ after the waterflooding stage. It was further found that the RF could be as high as $18.3 \%$ if $0.25 \mathrm{wt} . \%$ NCP was dispersed in a surface-active material (Polyvinyl alcohol, PVA in this study). The result was $4 \%$ higher than a scenario in which PVA was used alone. Moreover, it was shown that altering the composition of the preflush could increase the production to up to $11.3 \%$. A comparative analysis with single nanoparticle revealed that the EOR using $\mathrm{NCP}$ was six-fold higher compared to that of $\mathrm{SiO}_{2}$ taken alone and 1.5-fold lower than those of $\mathrm{Al}_{2} \mathrm{O}_{3}$ or $\mathrm{Fe}_{2} \mathrm{O}_{3}$ taken alone.
\end{abstract}

Keywords Nanocomposite $\cdot$ Nanoparticle $\cdot$ EOR $\cdot$ Heavy oil

\section{Introduction}

A composite is a material made from two or more components with significantly different physical and/or chemical properties (Kelly and Zweben 2000; Nguele et al. 2021). When at least one of the individual phases is within the size range of nanometer, the composite is referred as a nanocomposite or NCP (Camargo et al. 2009). The literature reports that as a material transits from micro- to nanometer scale, its individual properties are improved subsequent to an increase in the ratio surface-to-volume. Hussain et al. (2006) reviewed the influence of the nanoparticle diameter, that of the fibrous material, as well as the layer thickness.

They concluded that a decrease from micro- to nanometer range of either parameter suffices to alter the surface

Ronald Nguele

nguele@mine.kyushu-u.ac.jp

1 Resource Production and Safety Engineering Laboratory, Kyushu University, Fukuoka 819-0395, Japan

2 Department of Inorganic Chemistry, Faculty of Science, University of Yaoundé, Yaoundé, Cameroon area-to-volume ratio by three orders of magnitude. With the knowledge that the surface area ratio and the properties of a material govern both its chemical and physical interactions, it is evident that the properties of NCPs are different from a large-dimensional material of the same composition (Thostenson et al. 2005; Butler et al. 2013). As far as NCPs are concerned, the bulk material does not necessarily have to be in the nanometer range. It is common to encounter NCs whose size varies from milli-, micro-, or even to nanometer (Kelly and Zweben 2000).

NCPs are generally grouped according to the matrix onto which the composite is made. The matrix should be regarded as a metal atom, group of atoms or material. In this regard, three primary types of composites are encountered including metal matrix nanocomposites in which the NC is constructed around a metallic atom or alloy (Thostenson et al. 2005; Hussain et al. 2006). A polymer matrix nanocomposite is another type of NCP in which the matrix is a polymer and vinyl alcohol (Acayanka et al. 2019). They are favored because of the ease of production and their ductile nature; the third is a ceramic matrix nanocomposite, in which a 
nanoparticle (NP) powder is incorporated onto the matrix (Camargo et al. 2009).

Such types of NCPs have a good wear resistance, a high thermal stability, and an excellent chemical stability. The difference in the matrices gives a flexibility to NCPs which has been well exploited in the industry. Despite the wealth of literature covering the engineering applications of NCPs, to the best of our knowledge, few have investigated the potential for enhanced oil recovery (EOR) despite their attractive features. Green and Willhite (1998) reported that most of the untapped oil remains underground due to capillary forces that neither natural energy of the reservoir (primary production) nor the injection of foreign materials like water and gas (secondary process) can lower.

However, a nanomaterial can alter the surface charge of the rock in a manner that polar groups of the trapped oil are detached (Karimaie et al. 2006). Cheraghian and Hendraningrat (2016) reviewed the benefits of the addition of NPs to fluids injected in the reservoir with the further purpose of displacing the stranded oil. They concluded that wettability alteration, advanced drag reduction, strengthened sand consolidation, the interfacial tension (IFT), as well as the mobility ratio are few amongst different properties that are enhanced upon adding NPs. Furthermore, if one looks at the recent works on nano-EOR, it appears that not only does nano-EOR have a promising future, but also that most of the literature disregards NCs (Table 1).

A production scheme, close to a scenario which involves NCs, is reported by Tarek et al. They combined different NPs including alumina oxide (Al-NP), magnesium oxide $(\mathrm{Mg}-\mathrm{NP})$, and iron oxide (Fe-NP) to primary silica oxide (Si-NP) to displace stranded light oil (Tarek and El-Banbi 2015). They reported a high recovery factor (RF) when NPs were added compared to the scenario in which Si-NP was used alone. To reduce the cost, it would be rational to use a cheaper material that can act just like combined NPs. NCPs seem to stand as a good candidate. Therefore, herein is investigated the potential of NCP for EOR application in a heavy oil reservoir.

The present work will revolve around ceramic matrix nanocomposite, extracted from a bauxite ore. The physicochemical features of the NC and its inherent nanofluids are

Table 1 Recent development and prominent works on nanoparticles for EOR

\begin{tabular}{|c|c|c|c|c|c|c|c|}
\hline \multirow[t]{2}{*}{ Reference } & \multicolumn{2}{|l|}{ Nanofluid } & \multicolumn{3}{|c|}{ Formation and fluid properties } & \multirow{2}{*}{$\begin{array}{l}\text { Recovery factor } \\
(\%)\end{array}$} & \multirow{2}{*}{$\begin{array}{l}\text { Predominant } \\
\text { recovery } \\
\text { mechanisms }\end{array}$} \\
\hline & Nanoparticles (NP) & Base fluid & Oil type & Density $\left(\mathrm{g} / \mathrm{cm}^{3}\right)$ & Formation type & & \\
\hline $\begin{array}{l}\text { Ogolo et al. } \\
\text { (2012) }\end{array}$ & Silica oxide $\left(\mathrm{SiO}_{2}\right)$ & $0.5 \% \mathrm{NaCl}$ & Medium & 0.911 & Sandpack & $\sim 4.20$ & $\begin{array}{r}\text { Wettability } \\
\text { alteration }\end{array}$ \\
\hline $\begin{array}{l}\text { Hendraningrat } \\
\text { et al. (2015) }\end{array}$ & & $3 \% \mathrm{NaCl}$ & Light & 0.826 & Sandstone & $\sim 9.90$ & \\
\hline Li et al. (2013) & & & & & & $\sim 5.32$ & \\
\hline $\begin{array}{l}\text { Nguele et al. } \\
\text { (2019) }\end{array}$ & & $\begin{array}{c}\text { Polyvinyl } \\
\text { alcohol }\end{array}$ & & 0.860 & & $\sim 7.64$ & $\begin{array}{l}\text { Wettability } \\
\text { alteration IFT } \\
\text { reduction }\end{array}$ \\
\hline $\begin{array}{l}\text { Giraldo et al. } \\
\text { (2013) }\end{array}$ & Alumina oxide $\left(\mathrm{Al}_{2} \mathrm{O}_{3}\right)$ & $\begin{array}{l}\text { Anionic sur- } \\
\text { factant }\end{array}$ & Heavy & 0.939 & Sandstone & - & $\begin{array}{r}\text { Wettability } \\
\text { alteration }\end{array}$ \\
\hline $\begin{array}{l}\text { Ogolo et al. } \\
\text { (2012) }\end{array}$ & & $0.5 \% \mathrm{NaCl}$ & Medium & 0.911 & Sandpack & $\sim 5$ & \\
\hline $\begin{array}{l}\text { Hendraningrat } \\
\text { et al.( 2013) }\end{array}$ & & $3 \% \mathrm{NaCl}$ & Light & 0.826 & Sandstone & $\sim 10.5$ & \\
\hline $\begin{array}{l}\text { Ogolo et al. } \\
\text { (2012) }\end{array}$ & Iron oxide $\left(\mathrm{Fe}_{2} \mathrm{O}_{3}\right)$ & $0.5 \% \mathrm{NaCl}$ & Medium & 0.911 & Sandpack & $\sim-0.80$ & - \\
\hline $\begin{array}{l}\text { Kothari et al. } \\
\text { (2010) }\end{array}$ & & Oleic acid & - & - & & $\sim 24.1$ & $\begin{array}{l}\text { Viscosity } \\
\text { reduction }\end{array}$ \\
\hline $\begin{array}{l}\text { Tarek and El- } \\
\text { Banbi (2015) }\end{array}$ & $\left(\mathrm{SiO}_{2}+\mathrm{Al}_{2} \mathrm{O}_{3}+\mathrm{Fe}_{2} \mathrm{O}_{3}\right)$ & Brine & Mineral Oil & 0.919 & Sandstone & $\sim 9.49$ & $\begin{array}{l}\text { Driving } \\
\text { mechanism } \\
\text { is dependent } \\
\text { of the type of } \\
\text { nanoparticles }\end{array}$ \\
\hline $\begin{array}{l}\text { Hendraningrat } \\
\text { et al. ( 2013) }\end{array}$ & $\left(\mathrm{SiO}_{2}+\mathrm{Al}_{2} \mathrm{O}_{3}+\mathrm{TiO}_{2}\right)$ & 3 wt. $\% \mathrm{NaCl}$ & Light & 0.826 & & $\sim 9.9$ & \\
\hline $\begin{array}{l}\text { Haroun et al. } \\
(2012)\end{array}$ & $\left(\mathrm{CuO}+\mathrm{NiO}+\mathrm{Fe}_{2} \mathrm{O}_{3}\right)$ & Brine & Mineral Oil & 0.887 & Carbonate & $\sim 24.15$ & \\
\hline
\end{tabular}

${ }^{\mathrm{a}} \mathrm{CuO}$ copper oxide; $\mathrm{NiO}$ nickel oxide; table was amended from Sun et al. (2017) and Negin et al. (2016) 
evaluated. A series of coreflooding tests will be carried out to investigate their potential as displacing agents in siliceous formation. The influencing parameters, as well as the mechanisms pertaining to the production, will be discussed.

\section{Experimental section}

\section{Chemistry of nanocomposite}

\section{Extraction of nanocomposite from bauxite ore}

The nanocomposite was obtained upon physicochemical treatment of a natural bauxite soil, collected from Adamaoua region, Cameroon (Fig. 1a).

The bauxite was crushed to obtain a finely sieved powder before an acidic treatment more suitable than the Bayer's process for low grade Bauxite. Ten grams of the sample were introduced into a conical flask and further dissolved in $1 \mathrm{~L}$ of $\mathrm{HCl}(5 \mathrm{M})$. The mixture was then stirred and heated at $60^{\circ} \mathrm{C}$ for one hour. After cooling at room temperature, the solution was filtered to eliminate insoluble impurities.

The $\mathrm{pH}$ of the solution was adjusted to 10 by addition of ammonia solution. The precipitate was filtered and dried overnight in an oven at $80{ }^{\circ} \mathrm{C}$ before calcination at $300{ }^{\circ} \mathrm{C}$ to yield a brownish powder (Fig. 1b).

\section{Spectral characterization of nanocomposite}

The characterization was initiated by the determination of the phase structure of NCP was performed by powder X-ray diffraction (XRD, Rigaku RINT2100 diffractometer) that utilizes $\mathrm{CuKa}$ radiation. Both the instrument and emission source profiles were modeled using NIST LaB6 660 and 660 a profile standards.

The surface morphology was further investigated using a Hitachi, SU 3500 that combines both scanning electron microscopy (SEM) and an energy dispersive X-ray spectrometer (EDX). SEM photographs were taken by a low vacuum high sensitivity scanning electron microscope.

Two spectrophotometers were used for spectral analyses including a Jasco spectrophotometer (Model 4100, Japan)
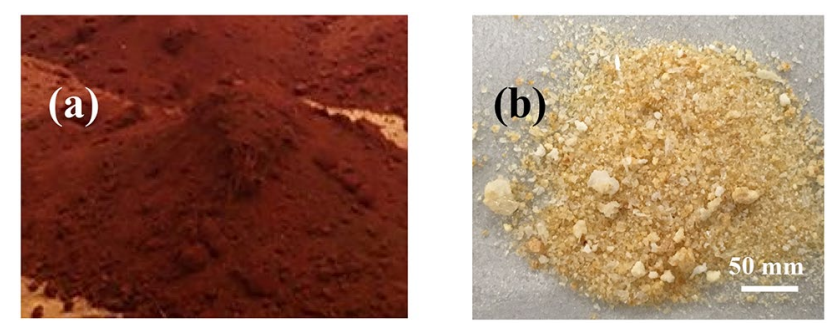

Fig. 1 Photographs of a original bauxite and $\mathbf{b}$ extracted NCP and ARAMIS spectrophotomer (Aramis Horiba, Japan). From the former, we acquired the FT/IR spectra, whereas the latter gave Raman spectra, which were obtained from microscopic laser Raman spectroscopy utilizing the $532 \mathrm{~nm}$ line of a Lexel $\mathrm{Ar}+$ laser.

\section{Preparation of nanofluid from nanocomposite}

The preliminary step of the study consisted in determining the optimal concentration in NCP set to be used for the subsequent experiments. That was performed by the conductivity method as per the procedure described elsewhere (Kenkel 2002). Five concentrations (0, 0.25, 0.50, 0.75 and $1 \mathrm{wt} . \%)$ were prepared by weighing and subsequently dispersing the corresponding mass of NCP into the synthetic formation water, chosen here as the base fluid. The conductivity was then measured using a conductivity meter (As One, AS650). Therefrom, the optimal concentration of 0.25 wt.\% was obtained.

To enhance stability, and to functionalize NCP, a two-step process was used. A nanofluid, with a concentration of 0.25 wt.\%, was prepared by dispersing $0.25 \mathrm{~g}$ of NCP in $100 \mathrm{~g}$ of base fluid. The mixture was then stirred for $1 \mathrm{~h}$ at 1000 RPM. At the end of the magnetic agitation, the NCF was subjected to an ultrasonic treatment at $40 \mathrm{kHz}$ in an ultrasonic bath (As One, MCD-3) for the same period.

During both magnetic mixing and sonication steps, carbon dioxide $\left(\mathrm{CO}_{2}\right)$ gas was continuously bubbled through the liquid at the rate of $0.5 \mathrm{ml} / \mathrm{min}$. This step is reported to enhance the stability of the material (Nguele et al. 2019).

\section{Potential of nanocomposite for enhanced heavy oil recovery}

\subsubsection{Materials}

Crude Oil A heavy mineral oil, purchased from Sigma Aldrich (USA), was used as candidate oil. It consisted of saturated and aromatic hydrocarbons only and has a density of $0.8535 \mathrm{~g} / \mathrm{cm}^{3}$ and a viscosity of $6.9 \mathrm{cP}$ at room temperature.

Synthetic formation water The synthetic oilfield water was prepared in-house as per the ionic concentrations shown in Table 2.

Hereinafter referred as SFW, the brine was prepared from sodium chloride $(\mathrm{NaCl})$ calcium chloride $\left(\mathrm{CaCl}_{2}\right)$, magnesium chloride hexa-hydrate $\left(\mathrm{MgCl}_{2}, 6 \mathrm{H}_{2} \mathrm{O}\right)$, sodium bicarbonate $\left(\mathrm{NaHCO}_{3}\right)$, and sodium sulfate $\left(\mathrm{Na}_{2} \mathrm{SO}_{4}\right)$. All the chemicals were purchased from Wako Pure Chemicals (Japan) except $\mathrm{NaCl}$, which was acquired from Junsei Chemicals (Japan). All the aqueous solutions were prepared using

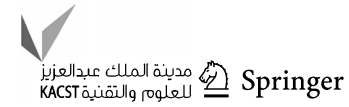


deionized water. It is worth noting that the chemicals were used as received.

Plugs and Preparation Berea sandstone was used to model the formation matrix. Prior to the experiment, the plug was dried overnight at $105^{\circ} \mathrm{C}$. The plugs parameters including the pore volume and the porosity were determined by gravimetric methods.

\section{Displacement assays}

The schematic of the apparatus used for oil displacement is shown Fig. 2.

It consists of an NS-KX (Model 201) pump used to inject tap water at a selected flow rate to the bottom part of the transfer cell filled with the fluid to be injected. The plug was mounted in a Hassler-type core holder and an overburden pressure, which varied from 1.5 to $2 \mathrm{MPa}$ depending on the permeability of the core was applied. The core was pre-flushed with deionized water to determine the water permeability of the plug.
At the end of which, approximately 2.5 pore volumes (PVs) of SFW were flooded into the sandstone. Another 2 $\mathrm{PV}$ of oil was then injected. No aging was performed on the sandstone. Both SFW and oil flooding were performed at flow rate of $1 \mathrm{~cm}^{3} / \mathrm{min}$. Both the preflush and the drive stages were conducted for $2 \mathrm{PV}$, at the flow rate of $1 \mathrm{~cm}^{3} /$ min using fresh water. Unless stated otherwise, henceforth the term water will refer to fresh water.

The nanofluid flooding, on the other hand, was conducted for $1 \mathrm{PV}$ at the same rate of $1 \mathrm{~cm}^{3} / \mathrm{min}$. The produced fluids were collected in a measuring cylinder. The inlet, outlet, differential, and annulus pressures were recorded using digital pressure gauges. In total, 11 flooding assays were conducted, and the summary is outlined in Table 3.

\section{Results and discussion}

The results of the present study will be divided into two major sections with the characterization of the extracted NCP acting as the introductory section. The second part of the work will present the results of the oil production with

Table 2 Ionic composition of synthetic formation water*

$\begin{array}{ll}\mathrm{Na}^{+}: 10.35 ; \mathrm{K}^{+}: 0.39 ; \mathrm{Mg}^{2+}: 1.08 ; \mathrm{Ca}^{2+}: 0.52 ; & \mathrm{Cl}^{-}: 18.62 ; \mathrm{HCO}_{3}^{-}: 0.12 ; \mathrm{SO}_{4}{ }^{2-}: 2.31\end{array}$

*All the compositions are given in ppm

Fig. 2 Schematic representation of coreflooding apparatus; (1) pump, (2) transfer cell containing the fluid to be injected, (3) gate valve, (4) pressure indicator, (5) Hassler core holder, (6) sandstone, and (7) fractionator

Table 3 Summary of coreflooding parameters*

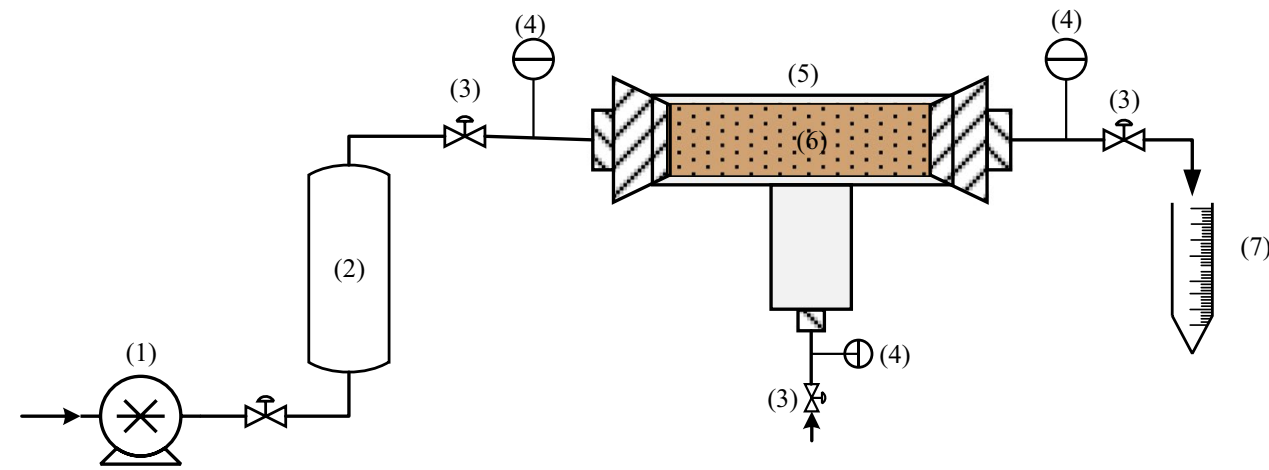

\begin{tabular}{|c|c|c|c|c|c|c|c|c|c|c|c|}
\hline Coreflood (CF) & $\# 1$ & $\# 2$ & \#3 & $\# 4$ & $\# 5$ & $\# 6$ & $\# 7$ & $\# 8$ & $\# 9$ & $\# 10$ & $\# 11$ \\
\hline$L(\mathrm{~cm}) \times D(\mathrm{~cm})$ & \multicolumn{11}{|c|}{$7.20 \times 4.54$} \\
\hline $\mathrm{PV}, \mathrm{cm}^{3}$ & 20.5 & 17.2 & 20.5 & 19.4 & 16.9 & 20.5 & 14.0 & 13.4 & 14.5 & & \\
\hline Porosity, $\%$ & 17.6 & 15.2 & 17.6 & 16.7 & 14.8 & 17.6 & 12.3 & 11.9 & 12.9 & & \\
\hline Residual oil & \multicolumn{11}{|c|}{ Heavy mineral oil (HMO) } \\
\hline Formation brine & \multicolumn{11}{|c|}{ Synthetic formation water (SFW) } \\
\hline TDS & \multicolumn{11}{|c|}{$7237 \mathrm{ppm}$} \\
\hline Salinity & \multicolumn{11}{|c|}{0.5 wt. $\% \mathrm{NaCl}$} \\
\hline
\end{tabular}

* $L$ length; $D$ diameter; $P V$ pore volume 
a focus given to the parameters altering the efficiency of the oil production. The crux of the paper will address the results of a comparative analysis between NCP and NPs.

\section{Physicochemical Features of Nanocomposite and Nanofluid}

XRD

The XRD spectra of NC are shown in Fig. 3.

The native bauxite shows the diffraction peaks at $2 \theta$ values of $21.40^{\circ}, 33.20^{\circ}, 36.70^{\circ}, 47.40^{\circ}$, and $54.22^{\circ}$ associated to goethite (Fig. 3a). Also, it could be observed XRD peaks at $2 \theta$ values of $20.32^{\circ}, 26.90^{\circ}, 28.04^{\circ}, 37.70^{\circ}, 44.20^{\circ}$, $45.46^{\circ}, 50.60^{\circ}, 52.22^{\circ}$, and $54.40^{\circ}$, which is ascribed to gibbsite (Chen 1977). It was found that an acidic treatment, followed by a calcination at $300^{\circ} \mathrm{C}$, these peaks either disappear or were less intense.

Tarkwa et al.(2019), who studied the influence of calcination of bauxite, argue that the disappearance of peaks associated to goethite and those ascribed to gibbsite are,

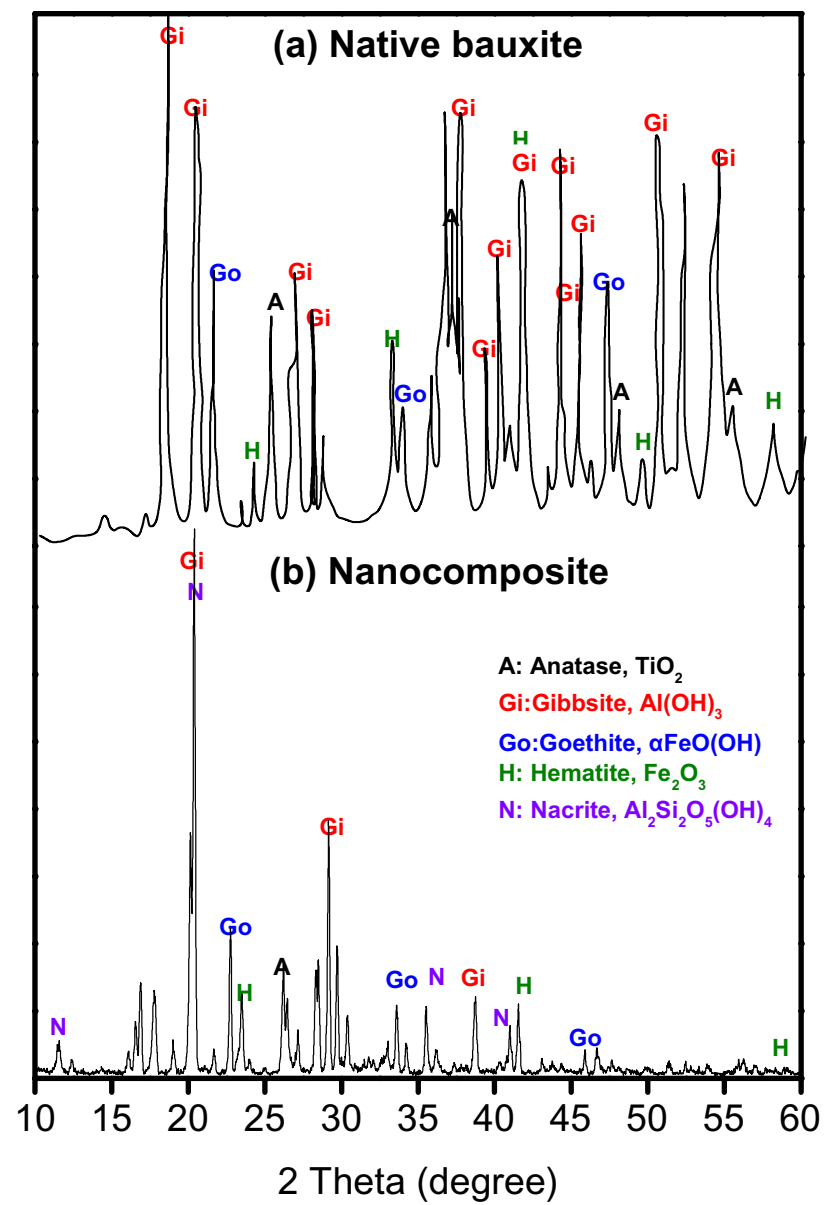

Fig. 3 XRD patterns of native bauxite and extracted NCP respectively, subsequent to dehydration into hematite, the dehydroxylation of gibbsite. As results of these concomitant mechanisms, its characteristic peaks at $2 \theta$ values of $26^{\circ}$ (210), $12^{\circ}(100), 40^{\circ}(222)$, and $43^{\circ}(320)$ show the presence of alumina in its the form $\alpha-\mathrm{Al}_{2} \mathrm{O}_{3}$ phase (Fig. 3a).

As per Chen (1977), extra peaks at $2 \theta$ values of $12^{\circ}(100)$, $26^{\circ}(210), 40^{\circ}(222)$ and $43^{\circ}$ (320) show the presence of alumina $\left(\mathrm{Al}_{2} \mathrm{O}_{3}\right)$ or silica in the form nacrite. Furthermore, the peaks at $17^{\circ}(110), 18^{\circ}(110), 26^{\circ}(210)$, and $28^{\circ}(210)$ could be indicative of the presence of a crystalline quartzbeta $\left(\beta-\mathrm{SiO}_{2}\right)$. That is a polymorphous $\mathrm{SiO}_{2}$ with a crystal structure very similar to that of quartz but with a higher symmetry (Heaney 1994).

\section{Elemental composition of extracted NCP}

Figure 4 shows the results of the elemental analyses as per conducted using EDX analysis.

With an initial atomic concentration in aluminum (Al) of about $26.7 \%$, in iron $(\mathrm{Fe})$ of $10.5 \%$ and silicon $(\mathrm{Si})$ of about $0.13 \%$, it could be seen that following the acid treatment the concentration in $\mathrm{Al}$ decreases by half-fold, while those of $\mathrm{Fe}$ and $\mathrm{Si}$ increase by 1 and 82 -fold. These results suggest that dissolution of goethite and gibbsite. Upon calcination, the recrystallization, subsequent to calcination, gives an NCP with a concentration in $\mathrm{Al} 1.3$ higher than the initial bauxite.

Applying the mole ratio, $\mathrm{NCP}$ has a weight composition of 64.5 wt. $\% \mathrm{Al}_{2} \mathrm{O}_{3}, 15.7$ wt. $\% \mathrm{Fe}_{2} \mathrm{O}_{3}$, and 19.8 wt. $\% \mathrm{SiO}_{2}$. It could be further seen that the concentration in Fe was fairly altered from either its initial value or after acid treatment. This observation was opposed to that of silica from which a concentration in the NCP increased by 50 -fold confirming thereby the presence of nacrite.

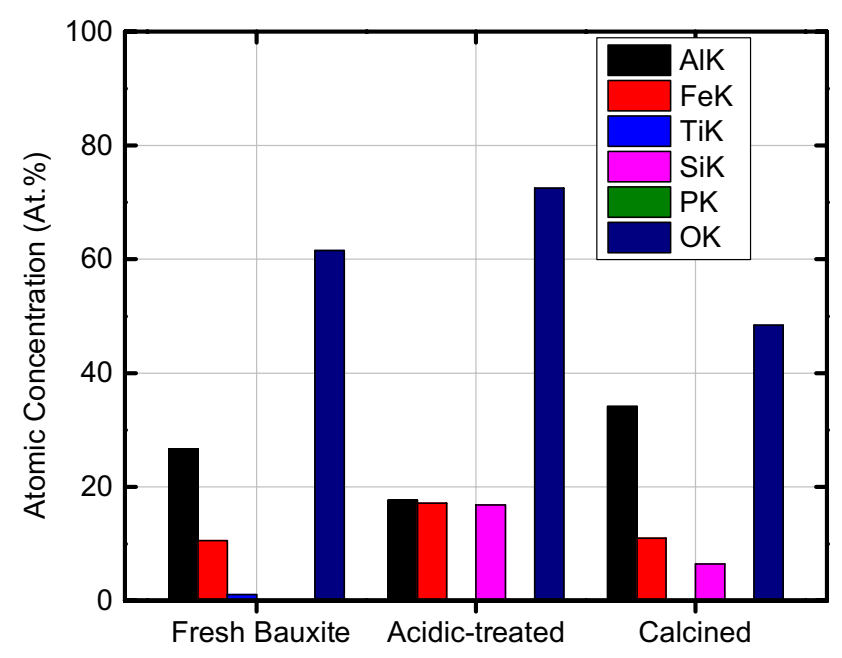

Fig. 4 Elemental composition obtained from EDX analysis

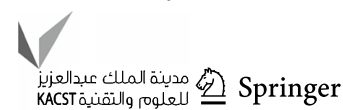




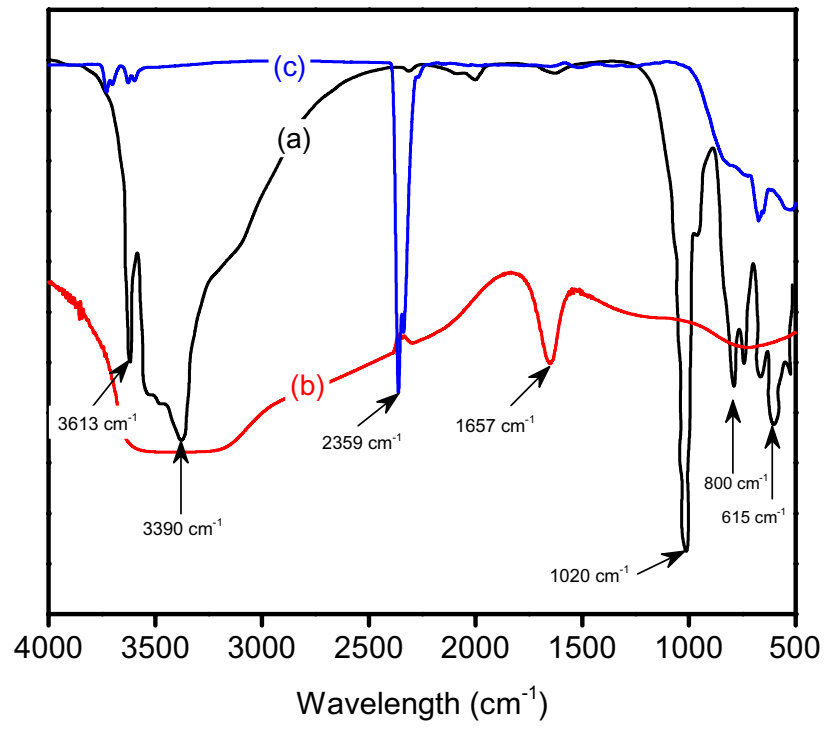

Fig. 5 Monitoring the formation of NCP by FTIR; a native bauxite, b bauxite after acid treatment, and $\mathbf{c}$ bauxite after acid treatment and calcination at $300^{\circ} \mathrm{C}$

\subsubsection{FTIR spectroscopy.}

Figure 5 shows the infrared spectra of the extracted NCP resulting from the acid treatment of the native bauxite.

The native bauxite, Fig. 5a, shows characteristic bands at $\sim 3613 \mathrm{~cm}^{-1}$ and $\sim 3390 \mathrm{~cm}^{-1}$ attributed to the stretching vibration of $\mathrm{OH}$ inherent to the presence of gibbsite and goethite (Cheng et al. 2010; Tarkwa et al. 2019). The presence of iron within the native bauxite could be seen at 800 and $615 \mathrm{~cm}^{-1}$ which are, respectively, attributed to stretching vibration of $\mathrm{Fe}-\mathrm{O}$ and $\mathrm{Fe}-\mathrm{O}-\mathrm{H}$ (Nakamoto 2009).

The shoulder at the IR band of $1020 \mathrm{~cm}^{-1}$ could be assigned to either to $\mathrm{Si}-\mathrm{O}-\mathrm{Si}$ stretching or to gibbsite $\mathrm{OH}$ groups bending (Russell 1977; Balan et al. 2006; Nayak and Singh 2007). Treating the native bauxite with acid, Fig. $5 b$, it could be seen that the peaks were either less pronounced or very broad. However, a shoulder appearing at the IR band of $1657 \mathrm{~cm}^{-1}$ was observed, which as per Ruan et al.(2002) is characteristic to an alteration of goethite to hematite.

The IR spectrum of NCP obtained after calcination, Fig. $5 c$, confirmed the occurrence of the chemical transformation of the bauxite. For instance, the shoulder at the IR band of $1020 \mathrm{~cm}^{-1}$ assigned to $\mathrm{Al}-\mathrm{OH}$ of the gibbsite group was less prominent in the NCP. This is due to its transformation to hematite $\left(1657 \mathrm{~cm}^{-1}\right)$, which is consistent with the literature(Ruan et al. 2002). These bands show the existence of a linkage Al-Si as well as the presence in Fe. Given the results of the FTIR and those of EDX, one may conclude that the NCP is mixture of $\mathrm{Al}_{2} \mathrm{O}_{3}, \mathrm{Fe}_{2} \mathrm{O}_{3}$, and $\mathrm{SiO}_{2}$.

\section{Formulation of nanofluid and apparent stability}

The quantitative analysis consisted of evaluating the stability of the formulated nanofluids, which was achieved spectrophotometry method (Ngo et al. 2020). This approach relied on the idea that a fully dispersed solution would have the same absorbance value at the same wavelength. The change in absorbance value should be regarded as the occurrence of either a homo- or hetero-aggregation.

Thus, the absorbance of the nanofluid, prepared as per the procedure described in the experimental section, was monitored for 12 days at room temperature using UV-Visible (Shimadzu, Model UV-24500). The results are shown in Fig. 6.

Monitored over 14 days at room temperature, the nanofluid starts to aggregate 2 days after dispersion as evidenced by the decrease in absorbance. The aggregation reaches its maximum value after 6 days and remains constant thereafter. The results contrasted with those of the base fluid (formation water), whose absorbance was constant through the observation period. Williams et al. (2006) reported that the stability of a nanofluid is in reality nonexistent.

$\mathrm{He}$ argued that the base fluid, at its best, can only prevent the nanomaterials from moving from unstable to stable energy states, which would lead to metastable nanofluid. Therefore, to use NCP as per the scheme proposed in this study, it was preferable to inject the solution within 2 days after its formulation.

\section{Application to EOR}

As part of an effort to evaluate the potential of NCP to increase the oil production, we conducted a series of 11

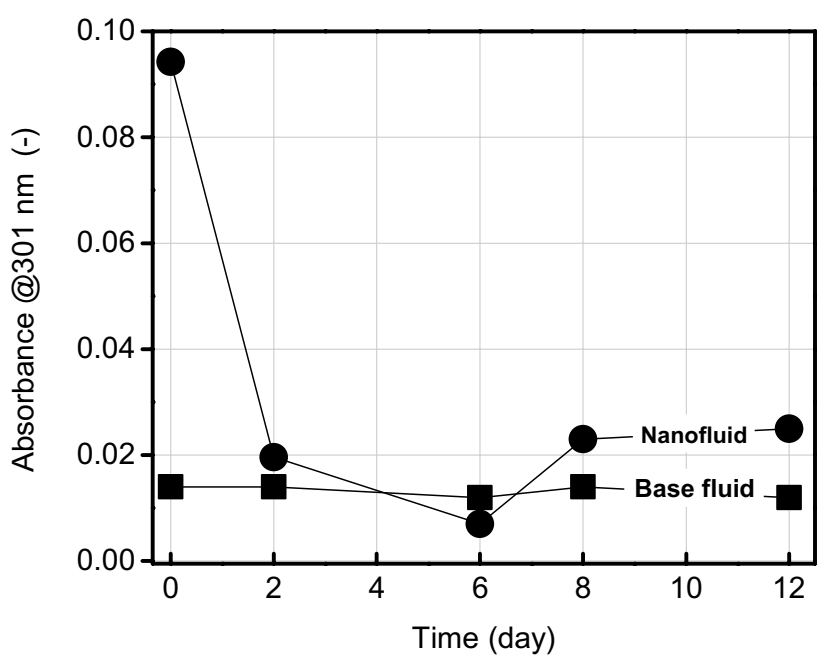

Fig. 6 Stability of nanofluid prepared from NCP at $25^{\circ} \mathrm{C}$ and nanofluid consisted in $0.25 \mathrm{wt} \%$ of $\mathrm{NCP}$ dispersed into the formation water 
coreflooding, at room temperature, i.e., $25{ }^{\circ} \mathrm{C}$. The results obtained and elaborated are summarized in Table 4.

\section{Baseline experiments}

The baseline experiment consisted of the injection of $\mathrm{NC}$ dispersed in SFW at the concentration of $0.25 \mathrm{wt}$. \% in sandstone. The results are shown in Fig. 7.

It was found that the preflush stage performed by injecting water (fresh water), yielded an RF of $61 \%$, with a water cut averaging $76 \%$. Both the increment in oil and the water cut were concurrent with an increase in pressure drop. While expecting an incremental increase in oil upon injecting 0.25 wt.\% NCF, the results stated otherwise. Looking at the displacement efficiency $\left(E_{\mathrm{D}}\right)$ as defined in Table 4 , it can be observed that injecting $0.25 \mathrm{wt}$.\% $\mathrm{NC}$ will not increment the $\operatorname{EOR}\left(E_{\mathrm{D}}=0\right)$.

The results were found intriguing given the elemental composition of the NCF. At this point, the possible reasons behind these results could be due to (1) the load of NCP, (2) the type of base fluid or (3) the interactions between the NCF and the formation fluids. Each of these points was then further assessed and the significance for oil production discussed.

\section{Contribution of the NCP load, base fluid type, and preflush composition.}

Influence of NC load Increasing the load in NP is reported to reduce the porosity of the core and/or to induce log-jamming (Torsater et al. 2012). However, with a proper load and size, the dispersed particles can propagate and increase the production. Thus, we increased the load in NCP from 0.25

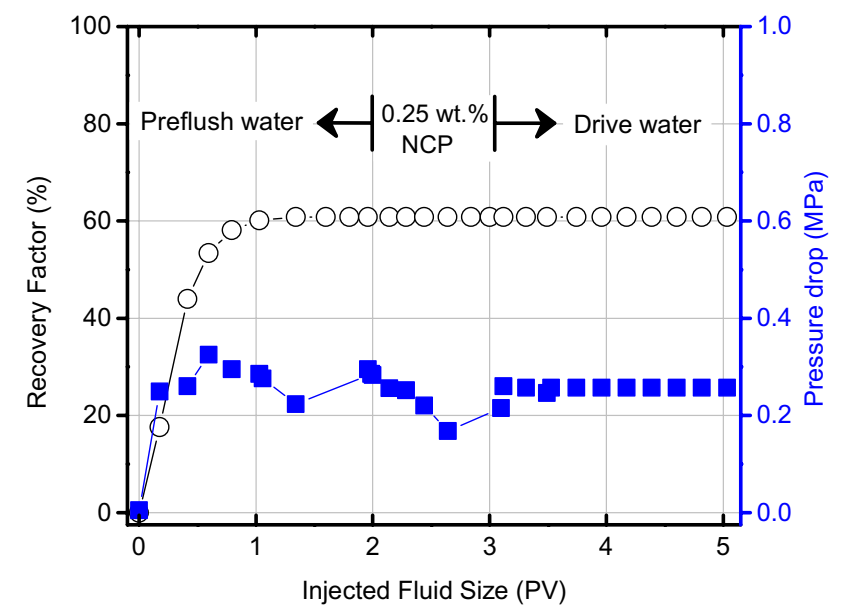

Fig. 7 Cumulative oil recovery as a function of injected pore volumes

wt. $\%$ to 0.75 and subsequently $1 \mathrm{wt} . \%$. This was achieved by dispersing a corresponding mass of NCP into the formation water. The results are shown in Fig. 8.

An increment in oil production increases with the concentration of dispersed NCP and was as high as14\% (Fig. 8a). Also, it could be seen that the pressure drop was weak at low concentration on NCP (Fig. 8b), but it subsequently increases with NCP load. We further observed that the oil was produced in a different fashion depending on the load of NCs. For example, when $1 \%$ NC was injected, the production started right after $0.2 \mathrm{PV}$ and increased steadily to reach its plateau value at $\sim 13 \%$ (Fig. 8 a).

The drive water could only displace $3.4 \%$ of the stranded oil. The same pattern was observed when the concentration was $0.75 \%$ at the difference that the oil production spiked

Table 4 Summary of the results from the coreflooding assays as per conducted in this study ${ }^{\mathrm{a}}$

\begin{tabular}{|c|c|c|c|c|c|c|c|c|c|c|}
\hline & \multirow{3}{*}{$\begin{array}{l}\text { Initial state } \\
S_{\mathrm{o}}(-)\end{array}$} & \multicolumn{2}{|c|}{ Preflush } & \multicolumn{5}{|c|}{ Nanocomposite/nanoparticle flooding } & \multirow[t]{3}{*}{ Drive water } & \multirow{3}{*}{$\mathrm{E}_{D}(\%)$} \\
\hline & & \multirow[b]{2}{*}{ Type } & \multirow[b]{2}{*}{$S_{\mathrm{o} 1}(-)$} & \multicolumn{2}{|l|}{ NPC (or NP) } & \multicolumn{2}{|l|}{ Base fluid } & \multirow[b]{2}{*}{$S_{\mathrm{o} 2}(-)$} & & \\
\hline & & & & NPC (or NP) & $C($ wt. $\%)$ & Type & $C$ (wt.\%) & & & \\
\hline CF-1 & 0.720 & DW & 0.282 & $\mathrm{NCP}$ & 0.25 & SFW & - & 0.282 & 0.282 & 0.0 \\
\hline $\mathrm{CF}-2$ & 0.630 & & 0.217 & & 0.75 & & & 0.186 & 0.182 & 14.1 \\
\hline $\mathrm{CF}-3$ & 0.717 & & 0.256 & & 1.00 & & & 0.222 & 0.213 & 13.4 \\
\hline $\mathrm{CF}-4$ & 0.828 & DW & 0.402 & NPC & 0.25 & $\mathrm{mPVOH}$ & 0.50 & 0.329 & 0.313 & 18.3 \\
\hline $\mathrm{CF}-5$ & 0.473 & & 0.337 & - & - & & & 0.278 & 0.254 & 17.5 \\
\hline CF-6 & 0.740 & $\mathrm{P}-1$ & 0.287 & NCP & 0.25 & SFW & - & 0.282 & 0.282 & 1.7 \\
\hline $\mathrm{CF}-7$ & 0.720 & $\mathrm{P}-2$ & 0.292 & & & & & 0.282 & 0.282 & 3.3 \\
\hline CF-8 & 0.700 & P-3 & 0.258 & & & & & 0.229 & 0.229 & 11.3 \\
\hline CF-9 & 0.896 & DW & 0.405 & Al-NP & 0.25 & $\mathrm{mPVOH}$ & 0.50 & 0.305 & 0.296 & 24.8 \\
\hline CF-10 & 0.679 & & 0.453 & $\mathrm{Fe}-\mathrm{NP}$ & & & & 0.324 & 0.320 & 28.4 \\
\hline CF-11 & 0.881 & & 0.363 & Si-NP & & & & 0.352 & 0.346 & 2.9 \\
\hline
\end{tabular}

${ }^{\text {a }}$ So: oil saturation; $C$ : concentration $E_{\mathrm{D}}$ : displacement efficiency $E_{D}=100 *\left(1-\left(S_{\mathrm{o} 3} / S_{\mathrm{o} 1}\right)\right)$ 
Fig. 8 Influence of nanocomposite load on waterflooded sandstones

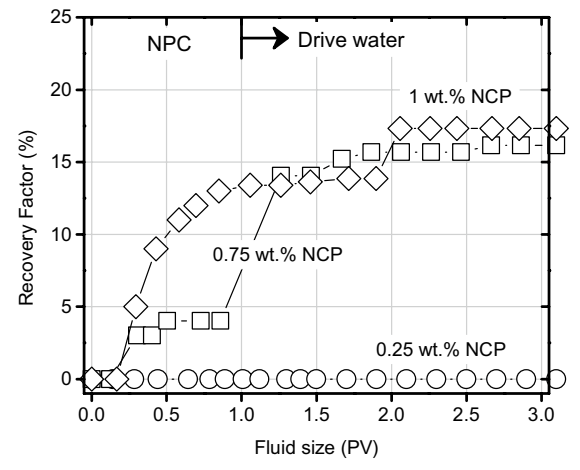

(a) recovery factor

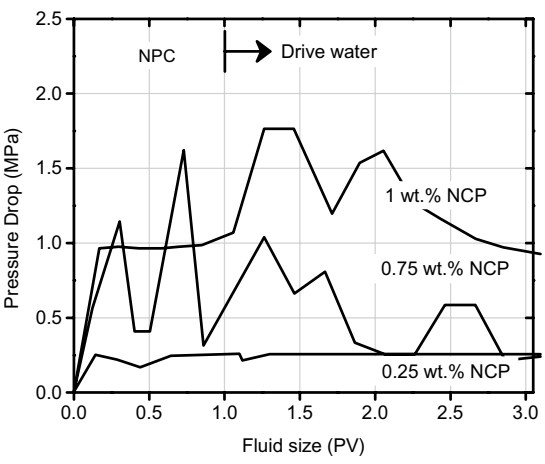

(b) pressure drop
Table 5 IFT and contact angle alteration as function of NCP concentration

\begin{tabular}{lllll}
\hline & Base fluid & \multicolumn{2}{l}{ NCP load } & \\
\cline { 3 - 5 } & & 0.25 wt.\% & 0.75 wt. $\%$ & 1.00 wt.\% \\
\hline IFT $(\mathrm{mN} / \mathrm{m})$ & 89 & 56.2 & 79.8 & 109.7 \\
Contact angle $\left({ }^{\circ}\right)$ & 107 & 115 & 20.0 & 20 \\
\hline
\end{tabular}

after $0.8 \mathrm{PV}$ to reach its plateau value $(\mathrm{RF}=14 \%)$ during the post flush stage. In this production scenario, RF was $38 \%$ lower (i.e., $\mathrm{RF}=2.1 \%$ ). Our results agree with the literature, which reports that a high concentration in nanomaterials increases the oil production (Hendraningrat et al. 2013; Kumar and Sharma 2018; Nguele et al. 2019).

To probe the underlying causes of the oil production, both the wettability (evaluated by contact angle measurements) and the interfacial tension were measured. The results are shown in Table 5.

It was found that the increase in NCP load has the ability to lower the contact angle, but it increases the IFT. If one looks at the production pattern (Fig. 8a), the pressure drop (Fig. 8b) as well as the results of IFT and wettability alteration (Table 5), one may be lead to the conclusion that the oil production pertains to an alteration of the interface oil/NCP.
Influence of base fluid type The literature conjectured that the mechanisms inherent to EOR using NP (and thus NCP) encompass IFT reduction, which in theory is achieved (or at least enhanced) by adding a foreign material (Negin et al. 2016). As far as the preparation of nanofluid is concerned, the main challenge is the choice of a base fluid, which in theory should (1) possess the ability to alter the physicochemical properties of the oil at the interface oil/rock, (2) have a minimal adsorption, and more importantly (3) provide a good dispersion.

As per the literature, polymer-based materials, such as polyvinyl alcohol or $\mathrm{PVOH}$ stand out as suitable candidates (Sharma et al. 2016; Kumar et al. 2020). Thus, a modified $\mathrm{PVOH}$ (hereinafter $\mathrm{mPVOH}$ ) was selected. The choice was motivated from the promising results obtained in our previous work (Nguele et al. 2019). The nanofluid, consisting of NCP $(0.25$ wt.\%) dispersed in 0.75 wt. \% of $\mathrm{mPVOH}$, was then prepared as per the procedure described in the experimental section.

The results of the oil production are shown in Fig. 9.

Injecting a nanofluid formulated using $\mathrm{mPVOH}$ in a waterflooded sandstone $(\mathrm{RF}=51.4 \%)$, approximately $20 \%$ of the stranded oil was displaced (Fig. 9a) which was accompanied by an increase in pressure drop (Fig. 9b). While in the meantime, only $17.5 \%$ of the stranded oil was displaced in
Fig. 9 Influence of the base fluid on heavy oil production

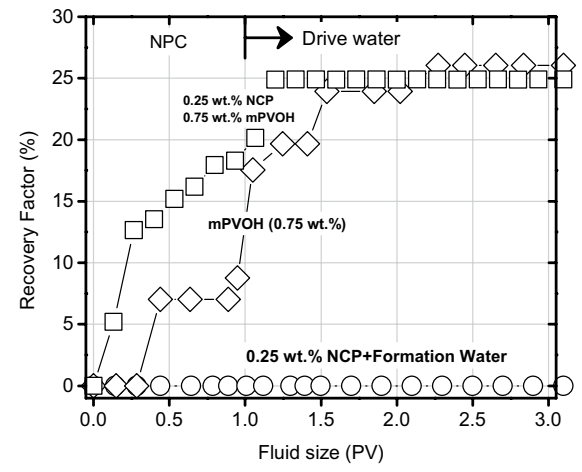

(a) Oil production

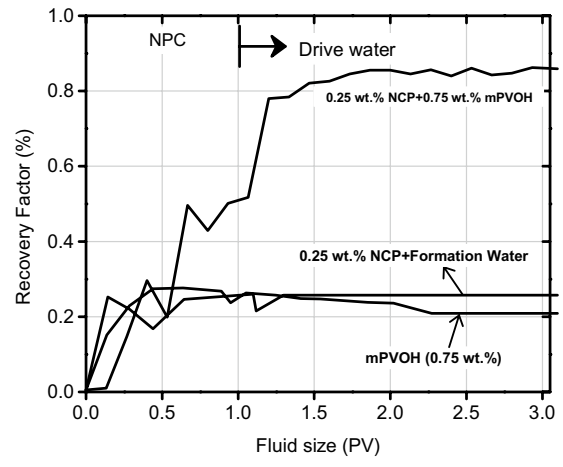

(b) Pressure drop 
a scenario in which $\mathrm{mPVOH}$ was injected alone. The drive water injected at the trail of nanofluid formulated using mPVOH displaced only $4.7 \%$.

This result was approximately half of the case in which the polymer was injected alone. If the IFT is being considered as the driving mechanisms in these flooding schemes (Fig. 10), it is rational to think that the oil is pushed out of the pore throats after a weakening of the van der Waals forces that keep the oil trapped.

Figure 10 shows further that blending the NCP with a surface-active material has the potential to lower the IFT. For example, altering the base fluid from formation water to the polymer, the IFT decreases of about $81 \%$. However, the addition of the $0.25 \mathrm{wt} . \%$ of NCP, the IFT decreases only by $45 \%$. This suggested the occurrence of synergistic effect between the NCP of the polymer. For instance, the addition of the NCP within the polymer increases the IFT of about $50 \%$.

The probable reason could be imputed to the polar-polar interactions occurring between the hydroxyl ends of the polymer and the mineral oil (Kronger et al. 2014).

Influence of the preflush composition In theory, the composition of the preflush should be tailored in the manner to promote favorable conditions for the nanofluid to displace

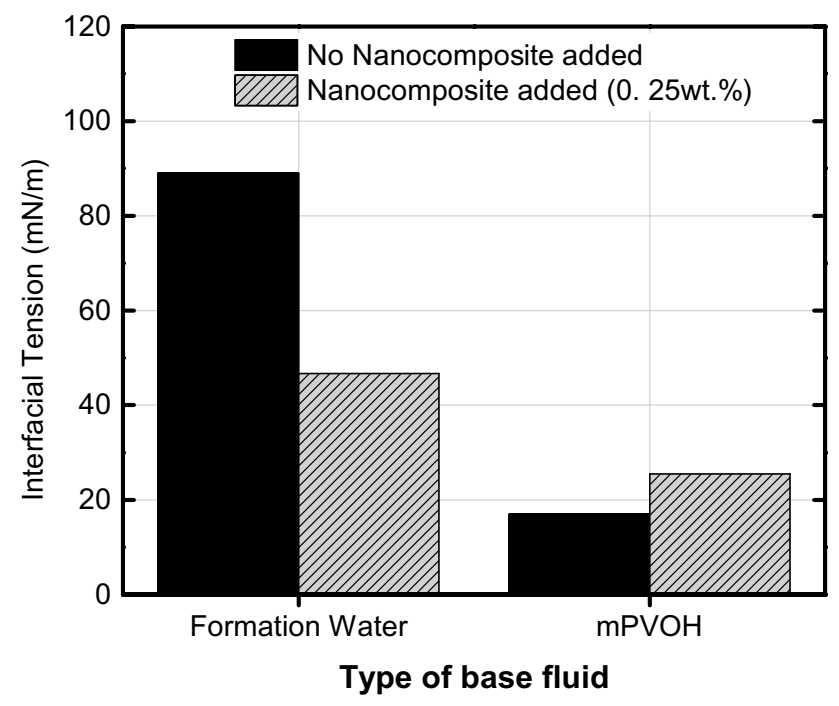

the oil. The preflush could be either a low saline or even fresh water. The latter case was considered in this study and yielded a poor displacement efficiency for the nanofluid $\left(E_{\mathrm{D}}=0\right.$, Table 4$)$. Thus, to improve the production, we sought to alter the composition of the preflush.

As per the detailed approach used to formulate the different preflush water (Supplementary file), the compositions are outlined in Table 6.

The results of the coreflooding using P-1, P-2, and P-3 validate the idea that altering the preflush could potentially increase the oil production (Fig. 11).

With an average recovery during the water stage of $61 \%$, the influence of the preflush composition was clearly noticeable during the nanofluid flooding. In fact, the displacement efficiency increased by $1.7,3.3$, and $11.3 \%$ respectively when P-1, P-2, and P-3 were injected. Despite the promising results, we are unsure which added ion is responsible for the increase.

However, as per the ions tracking, their impact on IFT and the geochemistry (Appendix B, Supplementary File), one can guess that the preflush interacts with the rock surface through either a cationic exchange between the inorganic ions or hydrogen bonding between the oxygen of the injected water and hydrogen of the silanol $(\mathrm{Si}-\mathrm{OH})$ group of rock (Sauer 1987; Nguele et al. 2020; Ansah et al. 2020).

In the former scenario, there is the possibility of exchange between the couples $\mathrm{Al}^{3+}$ and $\mathrm{Ca}^{2+}$ (ion radius $1.06 \AA$ ), $\mathrm{Al}^{3+}$ and $\mathrm{Mg}^{2+}$ (ion radius $0.72 \AA$ ) or a cationic exchange between $\left(\mathrm{Na}^{+} / \mathrm{Ca}^{2+}\right.$ or $\left.\mathrm{Na}^{+} / \mathrm{Mg}^{2+}\right)$. These ions mix with the nanofluid in such a way that its matrix is altered. It is paramount to avoid more $\mathrm{Ca}^{2+}$ as it is detrimental to IFT reduction (Table 7).

In event where the exchange is promoted, Ansah et al. (2020) argued that the hydrogen bonding leads to the formation of weak acids, which polarizes the rock surface. These concomitant phenomena enhance wettability alteration. This complexity could be avoided by taking each ion singularly and further investigating the extent to which it impacts the production. This point is currently under investigation and will be addressed in separate work.

Fig. 10 Interfacial tension alteration as function of base fluid

Table 6 Compositions of the preflush water

\begin{tabular}{|c|c|c|c|c|c|c|c|}
\hline & $\mathrm{Na}^{+}(\mathrm{ppm})$ & $\mathrm{Mg}^{2+}(\mathrm{ppm})$ & $\mathrm{Cl}^{-}(\mathrm{ppm})$ & $\mathrm{CO}_{3}{ }^{2-}(\mathrm{ppm})$ & $\mathrm{SO}_{4}^{2-}(\mathrm{ppm})$ & $\begin{array}{l}\text { Salinity } \\
(\% \mathrm{NaCl})\end{array}$ & TDS (ppm) \\
\hline P-1 & 722.80 & & & 277.6 & 83.8 & 0.07 & 1084.2 \\
\hline P-2 & 3826.3 & 95.3 & 190.60 & 423.6 & 96.7 & 0.38 & 4632.5 \\
\hline P-3 & 7742.2 & & 4722.2 & 452.8 & 81.1 & 0.77 & $12,998.3$ \\
\hline
\end{tabular}


(a)
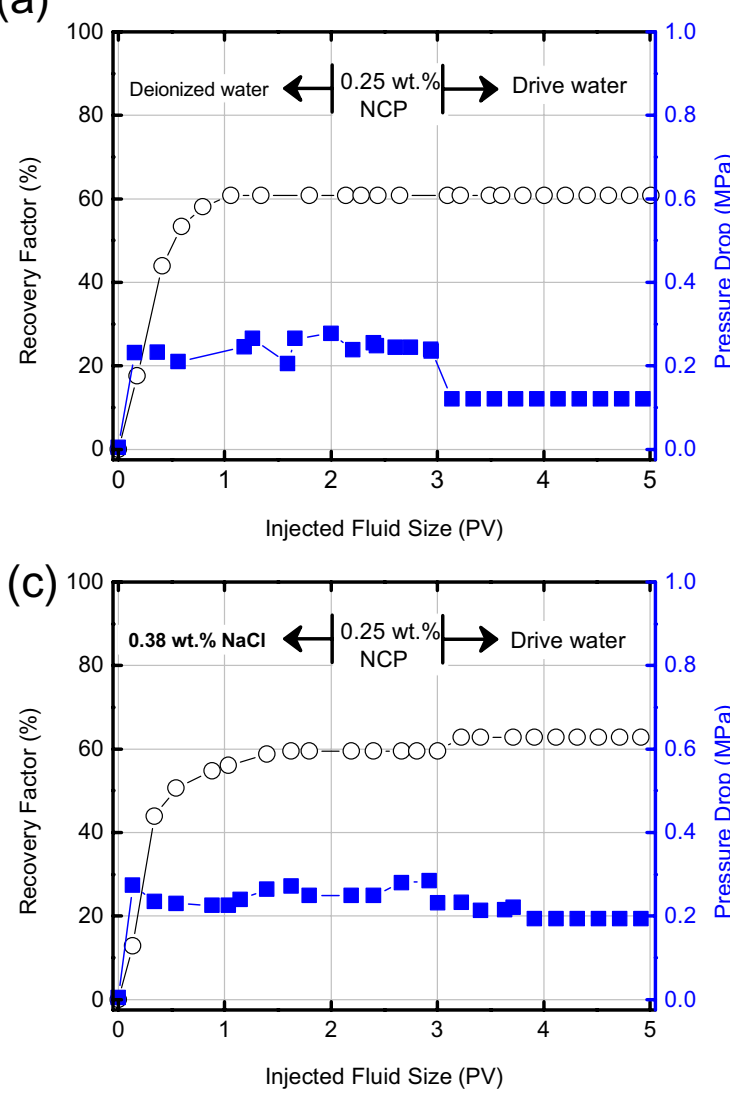

Fig. 11 Oil production, pressure drop as function of preflush composition (b)

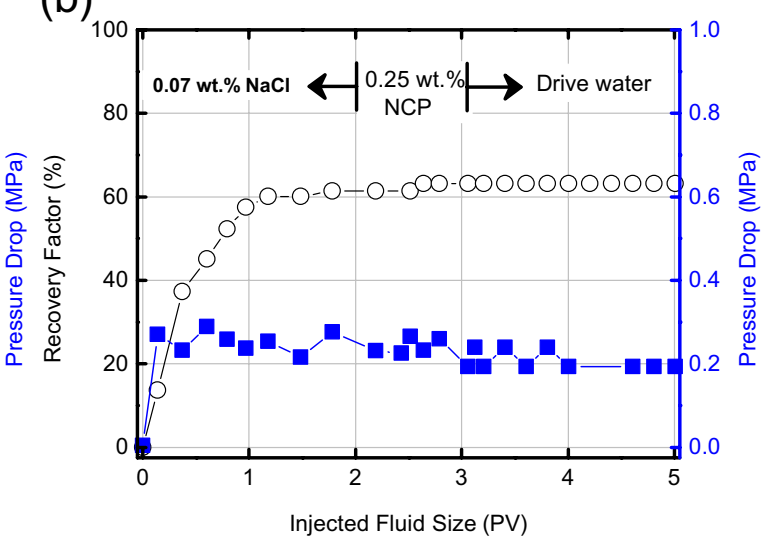

(d)

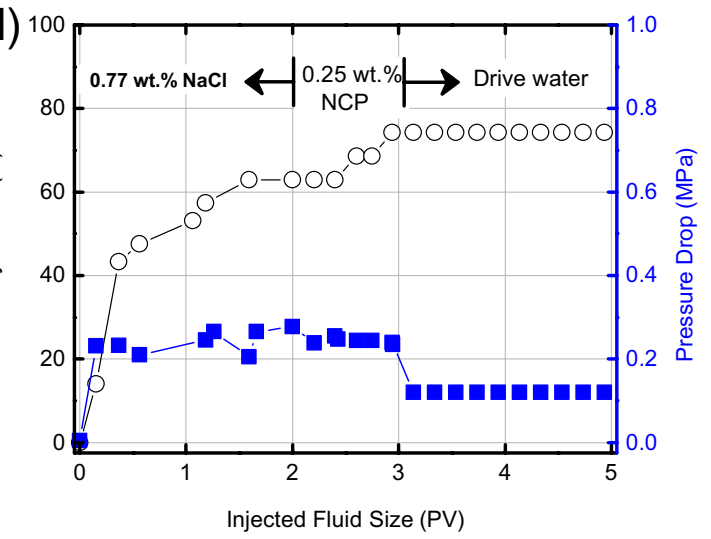

\section{Nanocomposite vs nanoparticle}

The oil recoveries from a waterflooded sandstones using nanofluids prepared from single nanoparticles were compared to that of nanocomposite (Fig. 12).

The nanoparticles were selected from the elemental composition of the NCP, which encompasses alumina oxide (Al$\mathrm{NP}$ ), iron oxide (Fe-NP), and silica oxide (Si-NP). Thus, we prepared three nanofluids using single NPs and $\mathrm{mPVOH}$ as base fluid. NPs were purchased from Tecnan (Spain) and have an average particle size of $15 \mathrm{~nm}$. Either of the formulated nanofluid was injected at the trail of the sandstone pre-flushed with fresh water.

For all the investigated nanofluids, the preflush stage displaces up to $49 \%$ of the oil-in-place. At the exception

Table 7 Interfacial tension alteration in function of preflush composition

\begin{tabular}{llccc}
\hline & DI & P-1 & P-2 & P-3 \\
\hline Salinity (wt.\%) NaCl & 0 & 0.07 & 0.37 & 0.67 \\
IFT (mN/m) & 52.1 & 65.5 & 48.5 & 44.8 \\
\hline
\end{tabular}

of Si-NP, the injection of nanofluid has the potential to recover, on the average, $36 \%$ of the stranded heavy oil compared to the scenario in which $\mathrm{mPVOH}$ was injected alone $\left(E_{\mathrm{D}}=17.5 \%\right.$, Table 4$)$. In fact, we obtained the highest recovery for Fe-NP $\left(E_{\mathrm{D}}=28.4 \%\right.$, Fig. $\left.12 \mathrm{~b}\right)$, and the lowest for Si-NP $\left(E_{\mathrm{D}}=2.86 \%\right.$, Fig. 12c).

Comparing the EOR obtained from single NPs and NPCs, it appears that both Al-NP and Fe-NP, which accounts, respectively, for $34 \%$ and $11 \%$ in the NPC, have a higher efficiency. Both NPs have an average EOR of $26.6 \%$, which was $47 \%$ higher compared to production in which NCP was used (Fig. 12d). However, NCP has a higher recovery compared to Si-NP taken alone (six-fold higher). These results suggest the existence of a synergistic effect in the presence of more than one oxide.

\section{Summary and conclusions}

Nanocomposite, NCP, was primarily a mixture of alumina $\left(\mathrm{Al}_{2} \mathrm{O}_{3}\right)$, iron $\left(\mathrm{Fe}_{2} \mathrm{O}_{3}\right)$, and silica oxide $\left(\mathrm{SiO}_{2}\right)$, with weight composition of 64.5 wt. $\% \mathrm{Al}_{2} \mathrm{O}_{3}, 15.7$ wt.\% $\mathrm{Fe}_{2} \mathrm{O}_{3}$, and 19.8 wt. $\% \mathrm{SiO}_{2}$. 


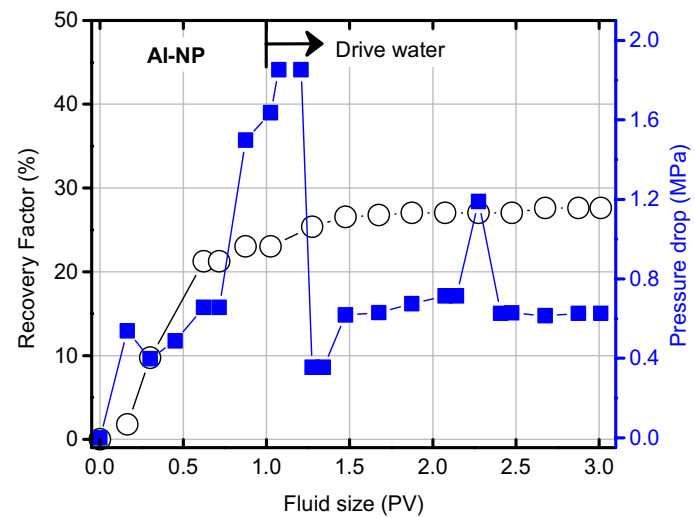

(a) Al-NP

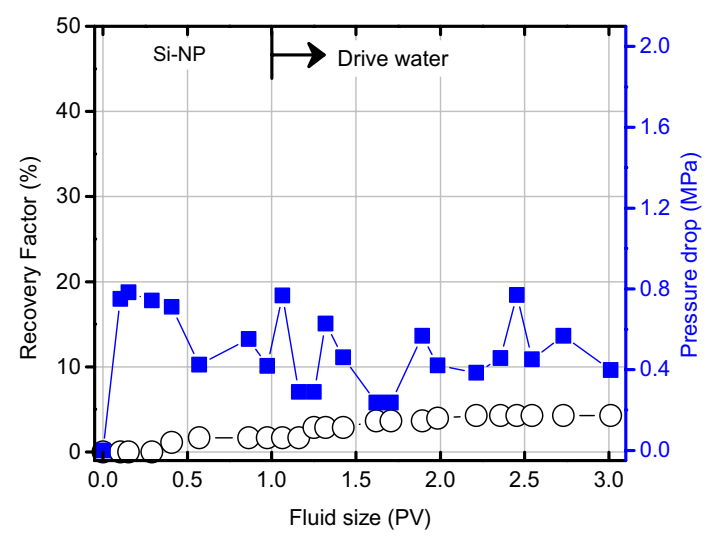

(c) $\mathrm{Si}-\mathrm{NP}$

Fig. 12 Comparative analysis between nanoparticle and nanocomposite

Nanofluid, prepared from NCP and dispersed in formation brine, remains metastable at $25^{\circ} \mathrm{C}$ for up to two days and exhibited a poor displacement efficiency in a waterflooded sandstone.

The recovery factor was improved subsequently from a waterflooded sandstone.

The load in NC was increased within the primary base fluid, i.e., formation brine (up to $13.4 \%$ );

The base fluid was changed from the formation brine to a surface-active material, polyvinyl alcohol in this study (up to $18 \%$ );

The preflush water composition was altered in a manner to inhibit the geochemical reactions occurring during the flooding (up to $11 \%$ ).

(d) The oil recovery obtained from waterflooded sandstone using NCP was six-fold higher compared to that of $\mathrm{SiO}_{2}$ taken alone and 1.5-fold lower than those of $\mathrm{Al}_{2} \mathrm{O}_{3}$ or $\mathrm{Fe}_{2} \mathrm{O}_{3}$ taken alone.

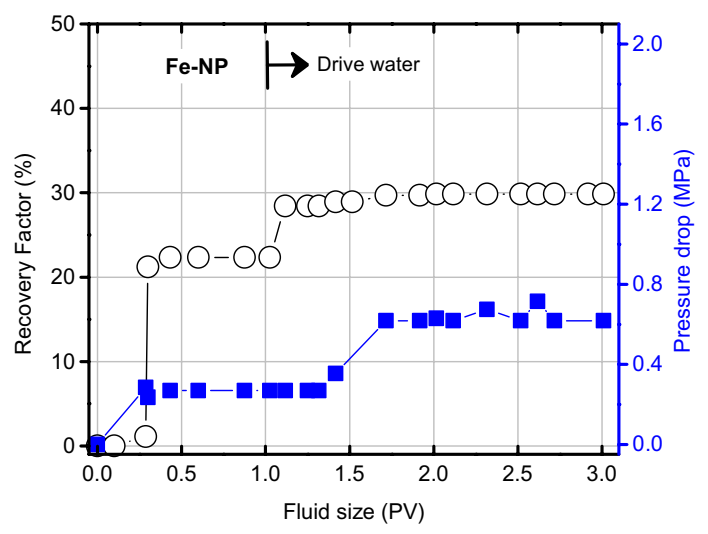

(b) Fe-NP

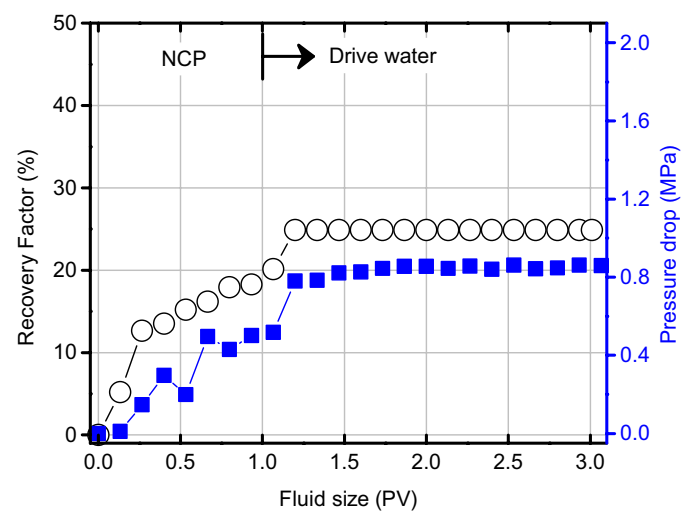

(d) NCP

Supplementary file 1 (DOCX $149 \mathrm{~kb}$ ) Supplementary Information The online version contains supplementary material available at(https://doi. org/10.1007/s13202-021-01112-6) .

Acknowledgments The present work was financially supported by the grant JSPS KAKENHI N ${ }^{\circ} 18 \mathrm{H} 05852$. The authors would like to extend their acknowledgement of Mitsubishi Chemicals for supplying the polymer used in this study. Also, Dr. Elie Acayanka (University of Yaoundé, Cameroon) for characterizing the native bauxite used in this study.

Author contributions All authors have approved the final version of the manuscript.

Funding The present work was financially supported by the grant JSPS Kakenhi JP 18H05852.

\section{Compliance with ethical standards}

Conflicts of interest There are no conflicts to declare. There are no conflicts to declare. 
Open Access This article is licensed under a Creative Commons Attribution 4.0 International License, which permits use, sharing, adaptation, distribution and reproduction in any medium or format, as long as you give appropriate credit to the original author(s) and the source, provide a link to the Creative Commons licence, and indicate if changes were made. The images or other third party material in this article are included in the article's Creative Commons licence, unless indicated otherwise in a credit line to the material. If material is not included in the article's Creative Commons licence and your intended use is not permitted by statutory regulation or exceeds the permitted use, you will need to obtain permission directly from the copyright holder. To view a copy of this licence, visit http://creativecommons.org/licenses/by/4.0/.

\section{References}

Acayanka E, Tarkwa J-B, Nchimi KN et al (2019) Grafting of $\mathrm{N}$-doped titania nanoparticles synthesized by the plasmaassisted method on textile surface for sunlight photocatalytic self-cleaning applications. Surf Interfaces 17:100361. https:// doi.org/10.1016/j.surfin.2019.100361

Ansah EO, Nguele R, Sugai Y, Sasaki K (2020) Predicting the antagonistic effect between albite-anorthite synergy and anhydrite on chemical enhanced oil recovery: effect of inorganic ions and scaling. J Dispers Sci Technol 42:21-32

Balan E, Lazzeri M, Morin G, Mauri F (2006) First-principles study of the OH-stretching modes of gibbsite. Am Mineral 91:115119. https://doi.org/10.2138/am.2006.1922

Butler SZ, Hollen SM, Cao L et al (2013) Progress, challenges, and opportunities in two-dimensional materials beyond graphene. ACS Nano 7:2898-2926

Camargo PHC, Satyanarayana KG, Wypych F (2009) Nanocomposites: synthesis, structure, properties and new application opportunities. Mater Res 12:1-39

Chen P-Y (1977) Table of key lines in X-ray powder diffraction patterns of minerals in clays and associated rocks. Bloomington, Indiana

Cheng H, Yang J, Liu Q et al (2010) A spectroscopic comparison of selected Chinese kaolinite, coal bearing kaolinite and halloysite-a mid-infrared and near-infrared study. Spectrochim Acta-Part A Mol Biomol Spectrosc 77:856-861

Cheraghian G, Hendraningrat L (2016) A review on applications of nanotechnology in the enhanced oil recovery part B: effects of nanoparticles on flooding. Int Nano Lett 6:1-10

Giraldo J, Benjumea P, Lopera S et al (2013) Wettability alteration of sandstone cores by alumina-based nanofluids. Energy Fuels 27:3659-3665

Green DW, Willhite GP (1998) Enhanced oil recovery. Society of Petroleum Engineers, Richardson

Haroun MR, Alhassan S, Ansari AA, et al (2012) Smart Nano-EOR Process for Abu Dhabi carbonate reservoirs. In: Abu Dhabi International petroleum conference and exhibition. Society of petroleum engineers. pp 1-13

Heaney PJ (1994) Silica. De Gruyter, Berlin, Boston

Hendraningrat L, Zhang J (2015) Polymeric nanospheres as a displacement fluid in enhanced oil recovery. Appl Nanosci 5:1009-1016

Hendraningrat L, Li S, Torsæter O (2013) A coreflood investigation of nanofluid enhanced oil recovery. J Pet Sci Eng 111:128-138

Hussain F, Hojjati M, Okamoto M, Gorga RE (2006) Review article: polymer-matrix nanocomposites, processing, manufacturing, and application: an overview. J Compos Mater 40:1511-1575
Karimaie H, Torsæter O, Esfahani MR et al (2006) Experimental investigation of oil recovery during water imbibition. J Pet Sci Eng 52:297-304

Kelly A, Zweben CH (2000) Comprehensive composite materials. Elsevier

Kenkel J (2002) Analytical chemistry for technicians, Third Edition. CRC Press

Kothari N, Raina B, Chandak KB, et al (2010) Application of ferrofluids for enhanced surfactant flooding in IOR. In: SPE EUROPEC/EAGE Annual conference and exhibition. Society of petroleum engineers

Kronger B, Holmberg K, Lindman B (2014) Surface and interfacial tension. Surface chemistry of surfactants and polymers. Wiley, Chichester, UK, pp 231-249

Kumar RS, Sharma T (2018) Stability and rheological properties of nanofluids stabilized by $\mathrm{SiO}_{2}$ nanoparticles and $\mathrm{SiO}_{2}-\mathrm{TiO}_{2}$ nanocomposites for oilfield applications. Colloids Surfaces A Physicochem Eng Asp 539:171-183

Kumar RS, Narukulla R, Sharma T (2020) Comparative effectiveness of thermal stability and rheological properties of nanofluid of $\mathrm{SiO}_{2}-\mathrm{TiO}_{2}$ nanocomposites for oil field applications. Ind Eng Chem Res 59:15768-15783

Li S, Hendraningrat L, Torsaeter O (2013) Improved oil recovery by hydrophilic silica nanoparticles suspension: 2-phase flow experimental studies. In: International petroleum technology conference. International petroleum technology conference

Nakamoto K (2009) Infrared and Raman Spectra of inorganic and coordination compounds: part A. Wiley, New Jersey

Nayak PS, Singh BK (2007) Instrumental characterization of clay by FTIR, XRF, BET and TPD-NH3. Bull Mater Sci 30:235-238

Negin C, Ali S, Xie Q (2016) Application of nanotechnology for enhancing oil recovery-a review. Petroleum 2:324-333

Ngo I, Sasaki K, Nguele R, Sugai Y (2020) Formation damage induced by water-based alumina nanofluids during enhanced oil recovery: influence of postflush salinity. ACS Omega 5:27103-27112

Nguele R, Sreu T, Inoue H et al (2019) Enhancing oil production using silica-based nanofluids: preparation, stability, and displacement mechanisms. Ind Eng Chem Res 58:15045-15060

Nguele R, Ansah EO, Nono KN, Sasaki K (2020) Albite-Anorthite synergistic effect on the performance of nanofluid enhanced oil recovery. European association of geoscientists and engineers, pp $1-11$

Nguele R, Nono KN, Sasaki K (2021) Nanocomposite and nanofluids: towards a sustainable carbon capture, utilization, and storage. IntechOpen. https://doi.org/10.5772/intechopen.95838

Ogolo NA, Olafuyi OA, Onyekonwu MO (2012) Enhanced oil recovery using nanoparticles. In: SPE Saudi Arabia section technical symposium and exhibition. Society of Petroleum Engineers

Rangel-German ER, Kovscek AR (2002) Experimental and analytical study of multidimensional imbibition in fractured porous media. J Pet Sci Eng 36:45-60

Ruan HD, Frost RL, Kloprogge JT, Duong L (2002) Infrared spectroscopy of goethite dehydroxylation: III. FT-IR microscopy of in situ study of the thermal transformation of goethite to hematite. Spectrochim Acta-Part A Mol Biomol Spectrosc 58:967-981

Russell JD (1977) H.W. Van der Marel and H. Beutelspacher Atlas of Infrared Spectroscopy of Clay Minerals and their Admixtures. Elsevier, Amsterdam 1976

Sauer J (1987) Molecular structure of orthosilicic acid, silanol, and $\mathrm{H}_{3} \mathrm{SiOH}$.cntdot. $\mathrm{AlH}_{3}$ complex: models of surface hydroxyls in silica and zeolites. J Phys Chem 91:2315-2319 
Sharma T, Iglauer S, Sangwai JS (2016) Silica nanofluids in an oilfield polymer polyacrylamide: interfacial properties, wettability alteration, and applications for chemical enhanced oil recovery. Ind Eng Chem Res 55:12387-12397

Sun X, Zhang Y, Chen G, Gai Z (2017) Application of nanoparticles in enhanced oil recovery: a critical review of recent progress. Energies 10:345. https://doi.org/10.3390/en10030345

Tarek M, El-Banbi AH (2015) Comprehensive investigation of effects of nano-fluid mixtures to enhance oil recovery. In: SPE North Africa technical conference and exhibition. Society of Petroleum Engineers

Tarkwa J-B, Acayanka E, Jiang B et al (2019) Highly efficient degradation of azo dye orange $\mathrm{g}$ using laterite soil as catalyst under irradiation of non-thermal plasma. Appl Catal B Environ 246:211-220
Thostenson ET, Li C, Chou T-W (2005) Nanocomposites in context. Compos Sci Technol 65:491-516

Torsater O, Engeset B, Hendraningrat L, Suwarno S (2012) Improved oil recovery by nanofluids flooding: an experimental study. In: SPE Kuwait International petroleum conference and exhibition. Society of Petroleum Engineers

Williams WC, Bang IC, Forrest E et al (2006) Preparation and characterization of various nanofluids. J Nanotech 2:408-411

Publisher's Note Springer Nature remains neutral with regard to jurisdictional claims in published maps and institutional affiliations. 